\title{
Hydrodynamics of a tropical estuary: Buranhém River, Porto Seguro, Brazil
}

\author{
Hidrodinâmica de um estuário tropical: rio Buranhém, Porto Seguro, Brasil
}

\author{
Ana Carolina Rodrigues de Sá Silva ${ }^{1}$, Marcos Eduardo Cordeiro Bernardes ${ }^{2}$, Arcilan Trevenzoli Assireu ${ }^{3}$, Eduardo Siegle ${ }^{4}$, \\ Paulo Henrique Gomes de Oliveira Sousa ${ }^{5}$ and Dustin Brown ${ }^{6}$ \\ ${ }^{1}$ Universidade Estadual Paulista, Guaratinguetá, SP, Brazil \\ ${ }^{2}$ Universidade Federal do Sul da Bahia, Eunápolis, BA, Brazil \\ ${ }^{3}$ Universidade Federal de Itajubá, Itajubá, MG, Brazil \\ ${ }^{4}$ Universidade de São Paulo, São Paulo, SP, Brazil \\ ${ }^{5}$ Universidade da Integração Internacional da Lusofonia Afro-Brasileira, Redenção, CE, Brazil \\ ${ }^{6}$ University of Guelph, Guelph, Ontario, Canada \\ E-mails: anacrdesasilva@gmail.com (ACRSS),marcos.bernardes@gmail.com (MECB), assireu@gmail.com (ATA), esiegle@usp.br (ES), \\ sousaph@gmail.com (PHGOS), dbrown24@uoguelph.ca (DB)
}

Received: August 28, 2017 - Revised: November 08, 2017 - Accepted: December 04, 2017

\begin{abstract}
Estuaries are dynamic environments that are highly vulnerable to anthropogenic influences, especially when adjacent to urban areas. In this study it is assessed for the first time the hydrodynamic characteristics of the Buranhém estuary (Northeast Brazil). The aim is to define the salt transport mechanisms and the hydrodynamics and stratification patterns of this tropical estuary, under both spring and neap tidal conditions. Fieldwork was carried out during 8 days covering varying tidal range conditions (July 30 ${ }^{\text {th }}$ to August $7^{\text {th }}$, 2015). Salinity and temperature were continuously monitored at moored stations at both the surface and bottom, whereas velocity profile was sampled by a bottom-mounted instrument. Average velocity in the water column was $0.46 \mathrm{~m} . \mathrm{s}^{-1}$ during flood tides and $1.0 \mathrm{~m} . \mathrm{s}^{-1}$ during ebb tides. Residual currents were seaward, with ebb dominance. The dominant salt transport mechanism is turbulent diffusion. Most of the layer Richardson values did not exceed 2, indicating well mixed conditions mainly during spring tides. Stratification varies with tide condition, with spring tides being able to further mix the vertical structure. Vertical velocity gradients that generate vertical mixing overcome the stabilizing effects generated by vertical density gradients.
\end{abstract}

Keywords: Tide; Stratification; Salinity.

\section{RESUMO}

Estuários são ambientes dinâmicos e altamente vulneráveis às influências antrópicas, em especial, nas áreas urbanas. Neste estudo, avalia-se pela primeira vez as características hidrodinâmicas do estuário do rio Buranhém (Nordeste do Brasil). Objetiva-se definir os mecanismos de transporte de sal e os padrões hidrodinâmicos e de estratificação desse estuário tropical, sob condições de maré de sizígia e quadratura. O trabalho de campo foi realizado durante 8 dias cobrindo uma variedade de condições de altura de maré (entre 30 de julho e 07 de agosto de 2015). A salinidade e a temperatura foram monitoradas continuamente na superfície e no fundo, enquanto o perfil de velocidade foi monitorado por um instrumento no fundo do canal. As velocidades médias foram de $0.46 \mathrm{~m} . \mathrm{s}^{-1}$, durante a maré de enchente, e $1.0 \mathrm{~m} . \mathrm{s}^{-1}$, durante a maré de vazante. As velocidades residuais foram no sentido de saída do estuário, com o domínio da vazante. O mecanismo de transporte de sal dominante foi difusão turbulenta. A maioria dos valores de número de Richardson por camada foi inferior a 2 , indicando que o estuário é bem misturado, principalmente, durante a maré de sizígia. A estratificação varia de acordo com a condição da maré, com as marés de sizígia podendo haver uma maior misturar na estrutura vertical. Os gradientes de velocidade vertical que geram misturas verticais superam os efeitos estabilizadores gerados pelos gradientes de densidade vertical.

Palavras-chave: Maré; Estratificação; Salinidade. 


\section{INTRODUCTION}

Coastal zones and their associated environments are among the regions of highest population density in Brazil (IBGE, 2013), and consequently, high anthropogenic pressure increases the vulnerability of these areas. One of such environments are estuaries, which are semi-enclosed bodies of water with an open connection to the ocean. In estuaries, there is mixture between continental freshwater and the saltwater provided by the adjacent ocean (CAMERON; PRITCHARD, 1963; PEREIRA et al., 2010). These environments provide a range of ecosystem services, such as the nurturing of life, coastal protection, purification of water, and carbon capture, among others.

Estuaries are vulnerable to human activity, since they are used for access to the interior of the continent, they are receiving bodies for natural and industrial effluents, and they are subject to high human occupancy rates in their surroundings (MIRANDA et al., 2002; PEREIRA et al., 2010).

One of the important components of the study of any given estuary is its hydrodynamics - or, the movement of water of the estuary - which in turn depends on processes which may be continental (e.g. river flow), atmospheric (e.g. wind and rain), and/or oceanic (e.g. tides and waves in general), with the impact of each process depending on its spatial and temporal scales.

Recent studies about estuarine hydrodynamics seek to generate a better understanding of processes like sediment transport (GONZÁLEZ et al., 2010), water quality (LIU et al., 2015), and ecological processes (TOWNEND et al., 2011), directly linked to the transport of energy and suspended matter.

In this study, it is assessed for the first time the hydrodynamics of the Buranhém river estuary (16²7’7.8” S, 39³’59.3” W, Figure 1). The Buranhém estuary is located in Porto Seguro, southern Bahia, Brazil. Porto Seguro is an important touristic destination in Brazil, resulting in high anthropogenic pressure with its surrounding area being densely populated. While the population of Porto Seguro is estimated on 150,000 inhabitants (IBGE, 2017), the number of tourists can reach up to 6 to 7 times its population per year.
This severely constrains water and sanitation systems during high season and has motivated the development of the municipal basic sanitation plan, which is under way. As most of the city's sewage is released in the Buranhém estuary, it is highlighted the importance of understanding local hydrodynamics.

There are only a few studies in the estuaries of southern Bahia, including some in the region adjacent to the Abrolhos Marine National Park, the largest coral reef habitat in the South Atlantic, approximately $120 \mathrm{~km}$ south of the Buranhém extuary. In this region, the Caravelas, Peruípe and Itanhém estuaries have been relatively well studied (e.g. PEREIRA et al., 2010; SCHETTINI; MIRANDA, 2010; ANDUTTA et al., 2013; PAIVA et al., 2016). These studies show the tide dominance in governing the estuarine processes, resulting in well mixed estuaries. Although being only $120 \mathrm{~km}$ to the north, due to the complex continental shelf morphology, the tidal range at the Buranhém estuary is about $1 \mathrm{~m}$ smaller than at the Caravelas region.

Therefore, the objective of this work is to understand the hydrodynamics of the Buranhém estuary and its stratification patterns based on hydrographic and velocity data and to show the dominant salt transport mechanism in up-estuary direction. Such information is presented for the first time for the Buranhém estuary and, in addition to the better understanding of its dynamics, it provides important background information for future studies in the region, such as water availability, sanitation and pollution.

\section{STUDY AREA}

The Buranhém River watershed spans approximately $2,500 \mathrm{~km}^{2}$, as it covers land in the Brazilian states of Minas Gerais and Bahia. The source of the river is in Serra dos Aimorés, in Santo Antônio do Jacinto, Minas Gerais, while its mouth and estuary is in the municipality of Porto Seguro, Bahia.

Based on Pereira et al. (2010), who studied the Caravelas and Peruípe estuaries (to the south of Porto Seguro, in the Abrolhos region), and on tidal charts of Porto Seguro

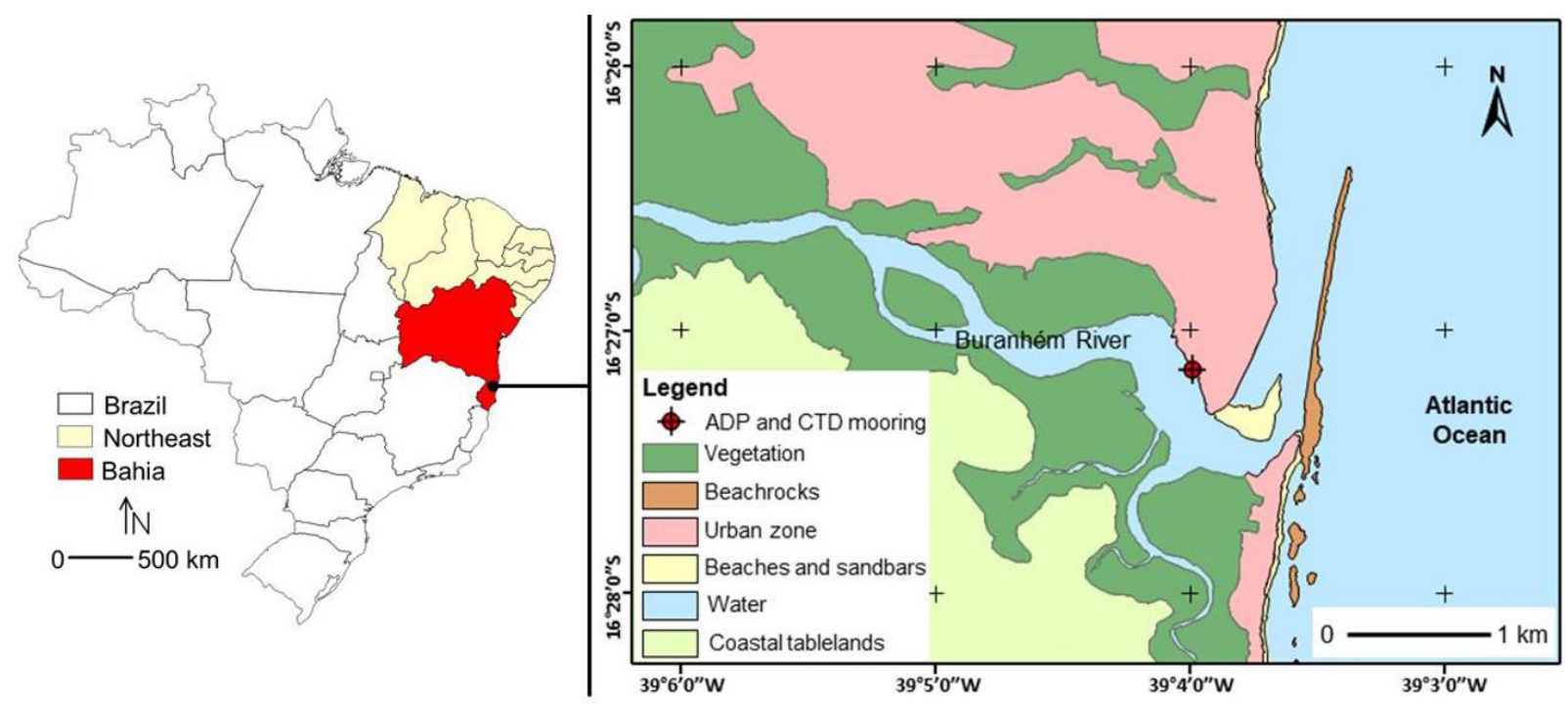

Figure 1. Buranhém river estuary, Porto Seguro, Bahia, Brazil. 
(http://www.tabuademares.com/br/bahia/porto-seguro), one may conclude that the region is subjected to an astronomical tide that ranges from micro to mesotidal conditions, with variations in the water level reaching just over $2 \mathrm{~m}$ under spring tide conditions.

In the study area, the reefs and coastal rocks located at the mouth of the Buranhém River (Figure 1) have a significant role in the local hydrodynamics by influencing a range of processes, such as directing the water entrance and forcing the outflow to be parallel to the coast during most of the tidal cycle.

The lower estuary presents large mangroves areas and a sandbar close to the inlet (Figure 1). The intertidal areas of the mangroves have a significant role in the estuarine tidal prism, being able to store a large volume of water during high-tides.

\section{MATERIALS AND METHODS}

\section{Hydrological data}

The National Water Agency (ANA, 2016) runs a fluviometric station in the Buranhém river that is known as Fazenda Limoeiro $\left(16^{\circ} 25^{\prime} 30^{\prime \prime} \mathrm{S}\right.$ and $\left.39^{\circ} 21^{\prime} 12^{\prime \prime} \mathrm{W}\right)$. Historical discharge data are available from January 1973 to January 2015. They indicate an average discharge value of $24 \mathrm{~m}^{3} \cdot \mathrm{s}^{-1}$, with seasonal variability (Figure 2). The same data source was used to define the discharge during the study period (July - August, 2015).

\section{Field measurements}

The field measurements included the mooring of a set of instruments in order to collect physical properties at the locations of interest. These included an Acoustic Doppler Profiler (ADP) with a pressure sensor (Nortek Aquadopp current profiler $1 \mathrm{MHz}$ ) and two CT sensors (JFE Advantech), with one being attached to the ADP frame on the bottom and the second fixed to a floating platform at a fixed depth of $0.2 \mathrm{~m}$ below the water surface. The sampling area was located in the estuarine channel approximately $2.5 \mathrm{~km}$ landward of its main inlet (16 $27^{\circ} 7.8^{\prime \prime}$ S, 39 3'59.3” W; Figure 1). Based on the local morphology, with sandbars and meanders, the sampling position has been defined in order to minimize the influence of lateral circulation, thus representing the estuarine circulation pattern.

The instruments collected velocity profiles in ten vertical bins $0.5 \mathrm{~m}$ high, water level, salinity and temperature data at 30 minute intervals from July 31, 2015 to August 7, 2015 (a total of 169 h). Depths at the mooring location varied from 3.3 to $5.4 \mathrm{~m}$ during data collection.

Velocity data were decomposed on longitudinal (parallel to main channel) and transversal components according to the estuary axis and were corrected for local magnetic declination. The main estuary axis was defined according to the channel orientation at the sampling station (approximately SE - NW-Figure 1). This was performed in such a way that positive values of longitudinal velocity indicate seaward currents.

Due to tidal influence, water column height is not constant over time. Therefore, the dimensionless depth was estimated using Equation 1 (MIRANDA et al., 2002), where the vertical axis is zero at the bottom and 1 at the surface:

$\mathrm{z}=\mathrm{z}_{\mathrm{c}} * \mathrm{~h}(\mathrm{t})^{-1}$

Where:

z: dimensionless depth [- ];

$\mathrm{z}_{\mathrm{c}}$ : cell height $[\mathrm{m}]$;

$\mathrm{h}(\mathrm{t})$ : total height $[\mathrm{m}]$ at time $\mathrm{t}$.

With these new dimensionless heights, the cubic spline method indicated by Miranda et al. (2002), Bérgamo (2000) and Cavalcante et al. (2013) was used in order to interpolate velocity values. According to these authors, this method improves the data adjustment through a third-degree polynomial.

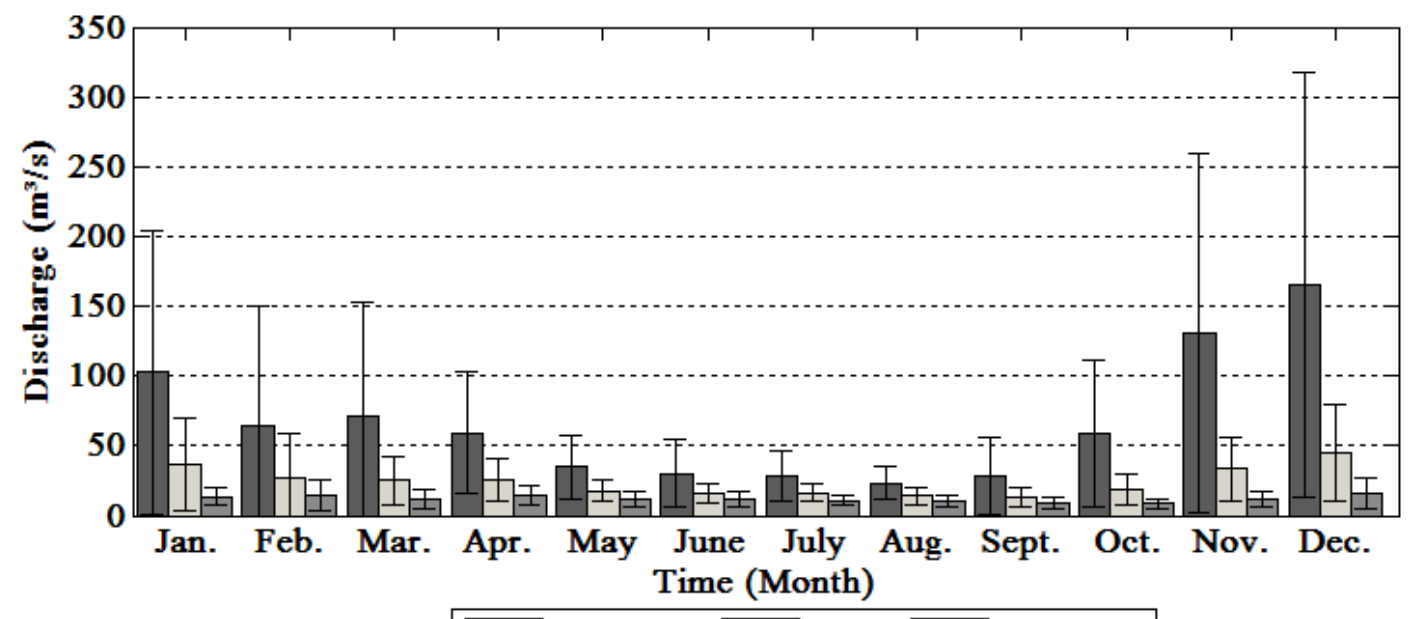

$\square$ Maximum $\square$ Mean $\square$ Minimum

Figure 2. Monthly average discharge data $\left(\mathrm{m}^{3} \cdot \mathrm{s}^{-1}\right)$ with standard deviation (vertical lines) at Fazenda Limoeiro between January 1973 and January 2015 (ANA, 2016). 


\section{Estuarine classification}

The estuary was classified for each complete tidal cycle according to the stratification-circulation diagram proposed by Hansen and Rattray Junior (1966). This classification shows the dominant salt transport mechanism in the upward direction, which can be either dispersive or advective (HANSEN; RATTRAY JUNIOR, 1966; SCOT'T, 1993).

The stratification parameter was estimated using Equation 2 (HANSEN; RATTRAY JUNIOR, 1966; DYER, 1997; MIRANDA et al., 2002; BÉRGAMO et al., 2002):

$\mathrm{P}_{\mathrm{e}}=\frac{\mathrm{S}_{\mathrm{f}}-\mathrm{S}_{\mathrm{s}}}{\overline{\mathrm{S}}}$

Where:

$P$ : stratification parameter (-);

$S_{f}$ salinity at the bottom (psu);

$S$ : salinity at surface (psu);

$\overline{\mathrm{S}}$ : average salinity of the water column (psu).

The circulation parameter was estimated using Equation 3:

$\mathrm{P}_{\mathrm{c}}=\frac{\mathrm{u}_{\mathrm{S}}}{\mathrm{u}_{\mathrm{f}}}$

Where:

$P_{i}:$ circulation parameter (-);

$u_{s}$ : residual current at the surface $\left(\mathrm{m} . \mathrm{s}^{-1}\right)$;

$u$ : velocity generated by river discharge $\left(\mathrm{m} . \mathrm{s}^{-1}\right)$.

The river discharge velocity $(u)$ was estimated by taking the averaged value in space and time of the water column, as proposed by Miranda et al. (2002).

The parameters calculated were plotted on the Hansen-Rattray Diagram using the MatLab code proposed by Bérgamo et al. (2002). This code plots the diagram along with the contour lines of parameter $\mathrm{v}$, which represents the relative proportion between turbulent dispersive and advective processes.

\section{Layer Richardson number}

The layer Richardson number is defined by Equation 4 (MIRANDA et al., 2002):

$$
\mathrm{Ri}_{\mathrm{L}}=\frac{\mathrm{gH} \Delta \rho_{\mathrm{v}}}{\rho \mathrm{u}^{2}} \approx \frac{\mathrm{gH} \beta \Delta \mathrm{S}_{\mathrm{v}}}{\mathrm{u}^{2}}
$$

Where:

$\mathrm{Ri}_{\mathrm{L}}$ : layer Richardson number;

g: acceleration of gravity $\left(9.81 \mathrm{~m} \cdot \mathrm{s}^{-2}\right)$;

$\mathrm{H}$ : local depth $[\mathrm{m}]$;

$\Delta p_{\mathrm{v}}$ : difference between densities at the riverbed and the surface $\left[\mathrm{kg} \cdot \mathrm{m}^{-3}\right]$;

$\rho$ : average density in the water column $\left[\mathrm{kg} \cdot \mathrm{m}^{-3}\right]$;

$\mathrm{u}$ : average velocity in the water column $\left[\mathrm{m} . \mathrm{s}^{-1}\right]$;

$\beta$ : average saline contraction coefficient $\left(\approx 7,0 * 10^{-4}\right)$;

$\Delta \mathrm{S}_{\mathrm{V}}$ : difference between salinity at the riverbed and at the surface.

Ranges for this number are used to define estuarine behavior:

if $\mathrm{Ri}_{\mathrm{L}}>20$, stratified conditions occur, since the generation of turbulence at the riverbed is insufficient to induce mixture; if $2<\mathrm{Ri}_{\mathrm{L}}<20$, the degree of mixture increases as the value decreases; and if $\mathrm{Ri}_{\mathrm{L}}<2$, there is total mixture (DYER, 1997).

The layer Richardson number allows for the evaluation of the relative importance between turbulence and vertical stratification at different moments of the tidal cycle. This dimensionless number characterizes the stability of the water column (BÉRGAMO et al., 2002).

$\mathrm{Ri}_{\mathrm{L}}$ was calculated throughout the whole time series. As the variables needed to calculate $\mathrm{Ri}_{\mathrm{L}}$ were measured every 30 minutes, $\mathrm{Ri}_{\mathrm{L}}$ was calculated every 30 minutes.

\section{RESULTS AND DISCUSSION}

\section{Hydrological data}

The river discharge at Fazenda Limoeiro during the study period is shown in Figure 3, where an average flow of $12.2 \mathrm{~m}^{3} . \mathrm{s}^{-1}$ was estimated, with a standard deviation of $0.3 \mathrm{~m}^{3} . \mathrm{s}^{-1}$. During the period of interest, the discharge varied from 11.8 to $12.8 \mathrm{~m}^{3} . \mathrm{s}^{-1}$, within the expected historical averages for the period (Figure 2).

Discharge values during the experiment (Figure 3) were within the historical range, corresponding to a dry period (Figure 2). Thus, the impact of this component was not considered in this work due to its minimal impact on the results when compared to tidal influence.

\section{Temperature, salinity, and vertical oscillation}

The spring tide period began on July 31 st 2015 and neap tide started on August 6 ${ }^{\text {th }}, 2015$ (Figure 4). The vertical oscillations of the water surface (Figure 4) showed that the maximum tidal range was $2.16 \mathrm{~m}$.

Surface and bottom temperatures are in phase (Figure 5 and Table 1), with a maximum difference of $1.53{ }^{\circ} \mathrm{C}$ and an average of $0.18 \pm 0.27^{\circ} \mathrm{C}$. The largest difference between the surface and bottom temperature was observed during the last three tidal cycles (starting on August $6^{\text {th }}$ ), during which there were small tidal amplitudes (Figure 4). The largest thermal stratification was, thus, observed during neap tides.

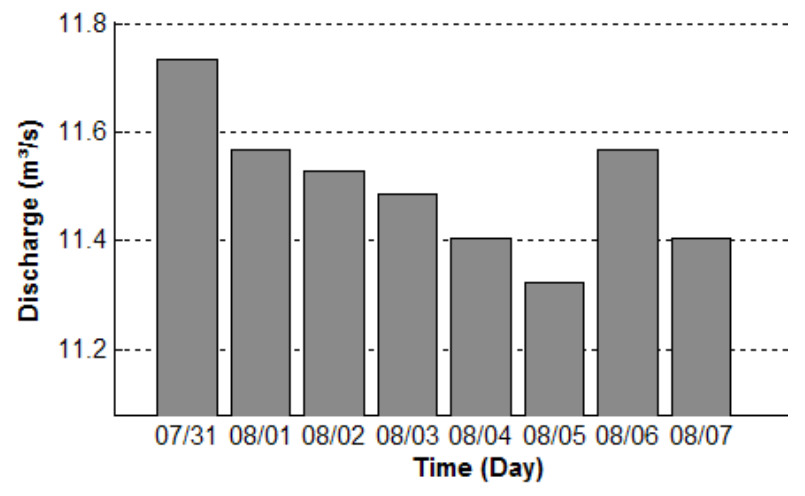

Figure 3. Daily data of discharge $\left(\mathrm{m}^{3} \cdot \mathrm{s}^{-1}\right)$ at Fazenda Limoeiro fluviometric station between July 31 and August 07, 2015 (ANA, 2016). 


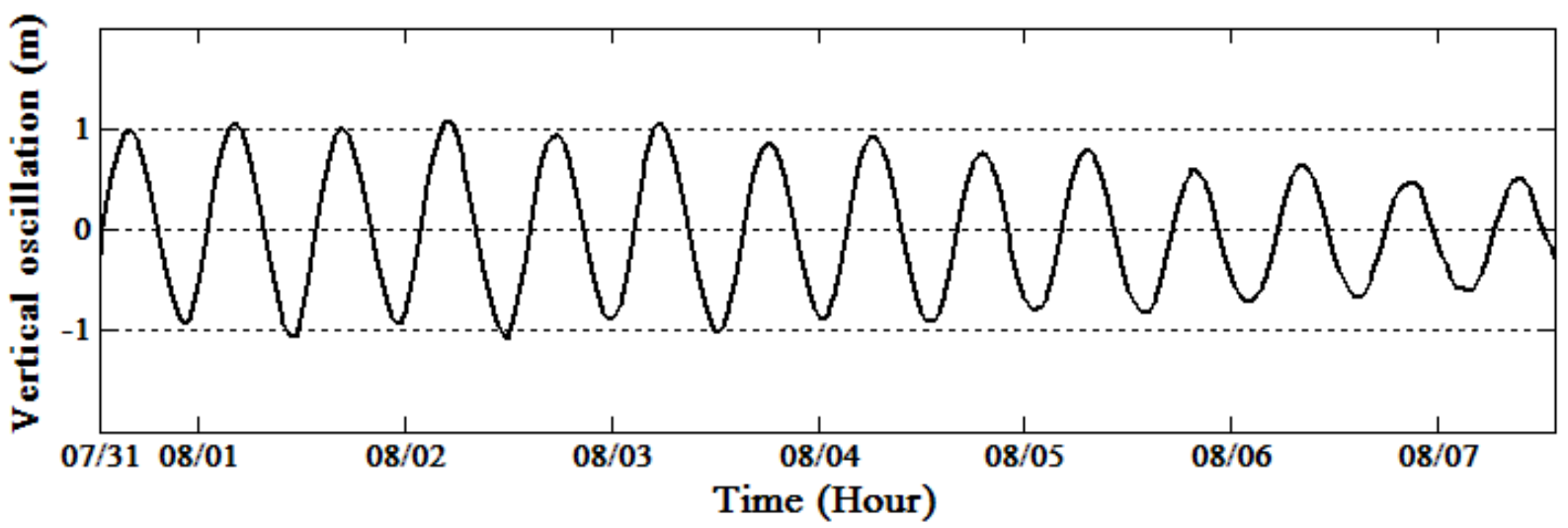

Figure 4. Data at 30 minute intervals of vertical oscillations (m) of the water surface from 12:30 pm on July 31,2015 to $1: 30$ pm on August 7, 2015.
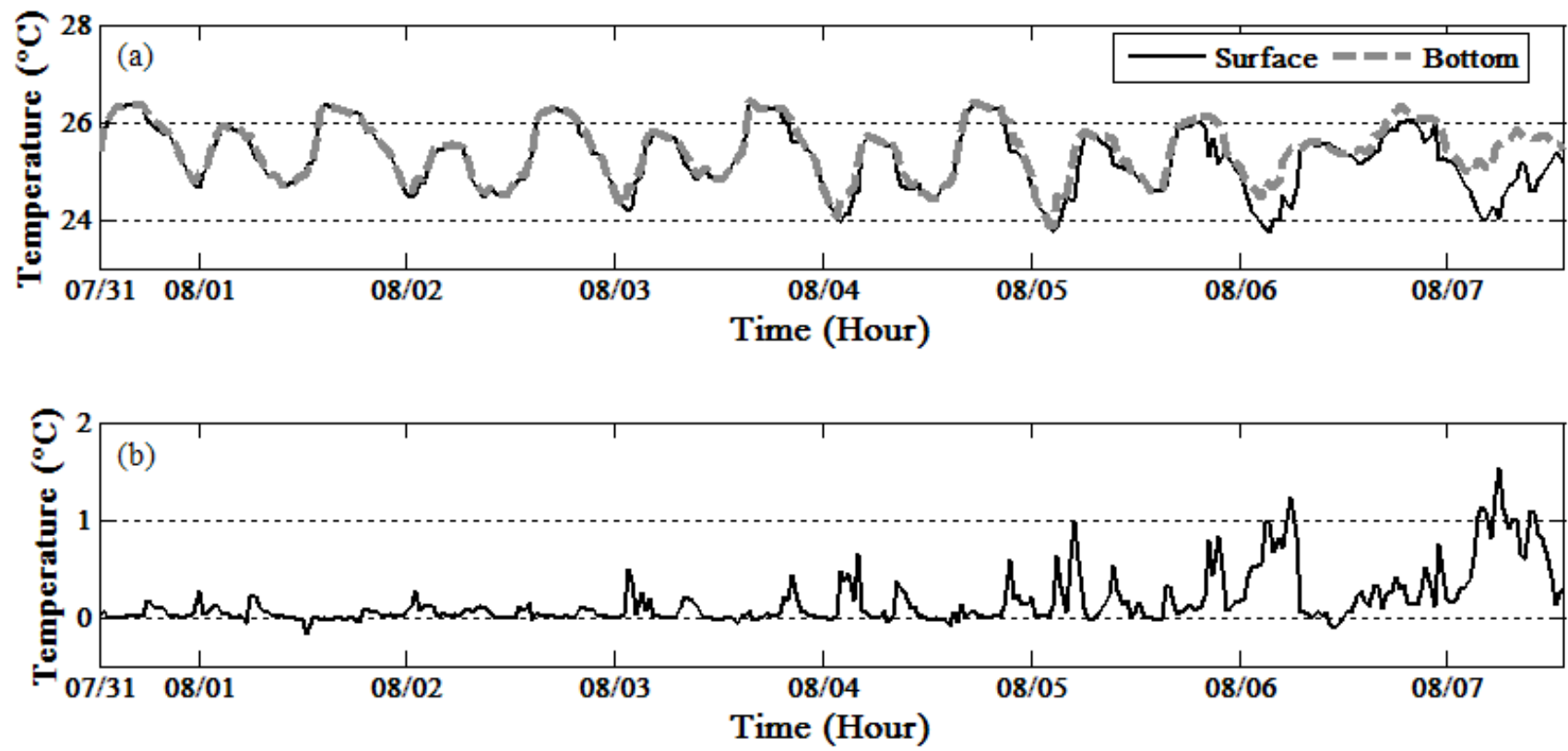

Figure 5. Data at 30 minute intervals of (a) Surface temperature $\left({ }^{\circ} \mathrm{C}\right.$; black and continuous line) and bottom temperature $\left({ }^{\circ} \mathrm{C}\right.$; gray dashed line) (b) difference between the surface and bottom temperature $\left({ }^{\circ} \mathrm{C}\right)$ from 12:30 pm on July 31, 2015 to 1:30 pm on August 7, 2015.

Table 1. Surface temperature and temperature at the bottom.

\begin{tabular}{lcc}
\hline Temperature $\left({ }^{\circ} \mathbf{C}\right)$ & Surface & Bottom \\
\hline Mean & 25.3 & 25.4 \\
Standard deviation & 0.7 & 0.6 \\
Minimum & 23.8 & 23.9 \\
Maximum & 26.5 & 26.4 \\
\hline
\end{tabular}

In general, temperatures at the bottom and surface were similar, indicating a negligible thermal stratification in the water column, apart from the last three cycles (Table 1).

Salinity at the bottom and surface were similar under spring tide conditions and during most of the study period (Figure 6). The exception was the neap tides period when salt stratification did occur. The maximum vertical difference of salinity was at neap tide.
Velocity

The longitudinal velocity (i.e. velocity parallel to the channel axis) data showed that the largest velocities occurred during the late stages of ebb tides (Figure 7). Data for average velocity in the water column had a maximum of $0.46 \mathrm{~m} . \mathrm{s}^{-1}$ during flood tides and $1.0 \mathrm{~m} . \mathrm{s}^{-1}$ during ebb tides. An analysis of the averaged velocity profile (Figure 8) shows surface velocity of $0.28 \mathrm{~m} \cdot \mathrm{s}^{-1}$ (ebb) and an average in the water column of $0.16 \mathrm{~m} \cdot \mathrm{s}^{-1}$ (ebb). Observed tidal asymmetry showed ebb dominance. With net flows and velocity being in the ebb direction, the estuary behaved as a potential exporter of matter towards the ocean, at least during the observed period (Figure 8).

Residual current was unidirectional and seaward (Figure 8), which is a characteristic of a well-mixed estuary (ANDUT'TA et al., 2013) and influenced by the large mangrove areas that are able to store a large volume of water (e.g. WOLANSKI, 1992; MAZDA et al., 1995; RIGO, 2004; ASP et al., 2012; GOMES et al., 2013). 

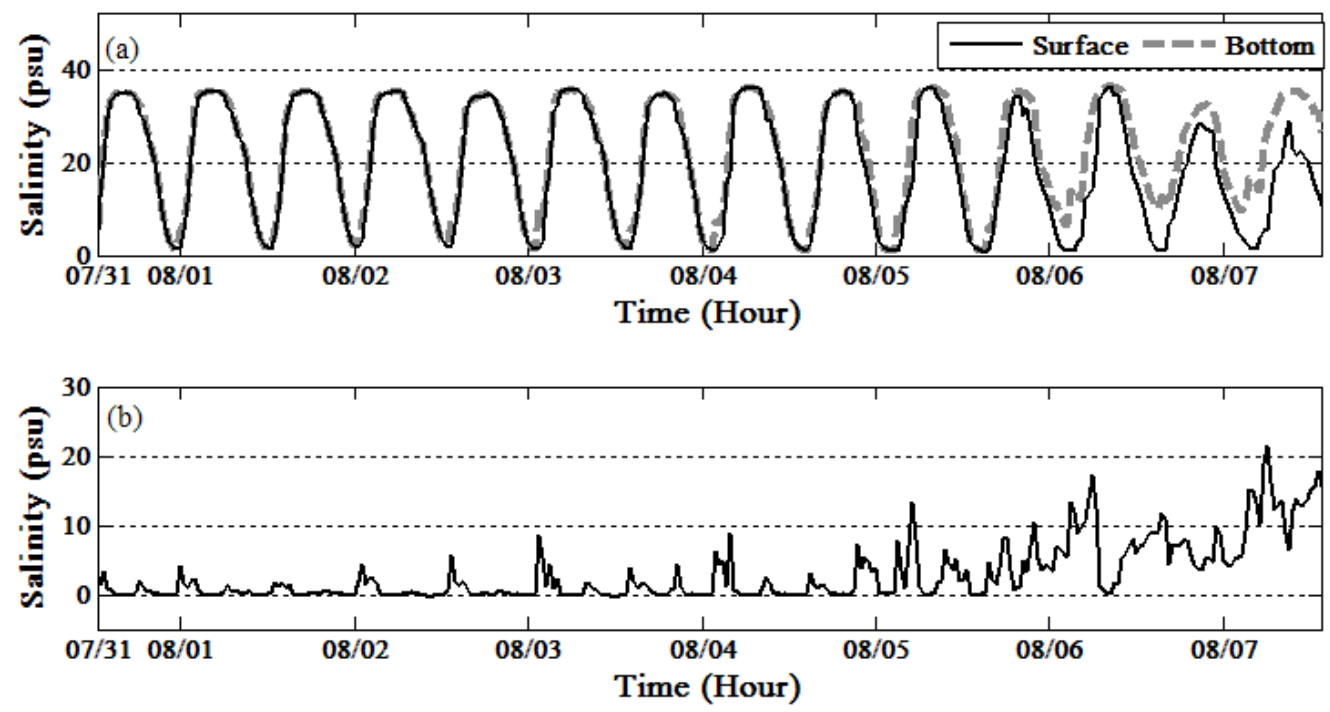

Figure 6. Data at 30 minute intervals of (a) Surface salinity (black continuous line) salinity at the bottom (gray dashed line) (b) difference between the surface and base salinity (psu) from 12:30 pm on July 31, 2015 to 1:30 pm on August 7, 2015.

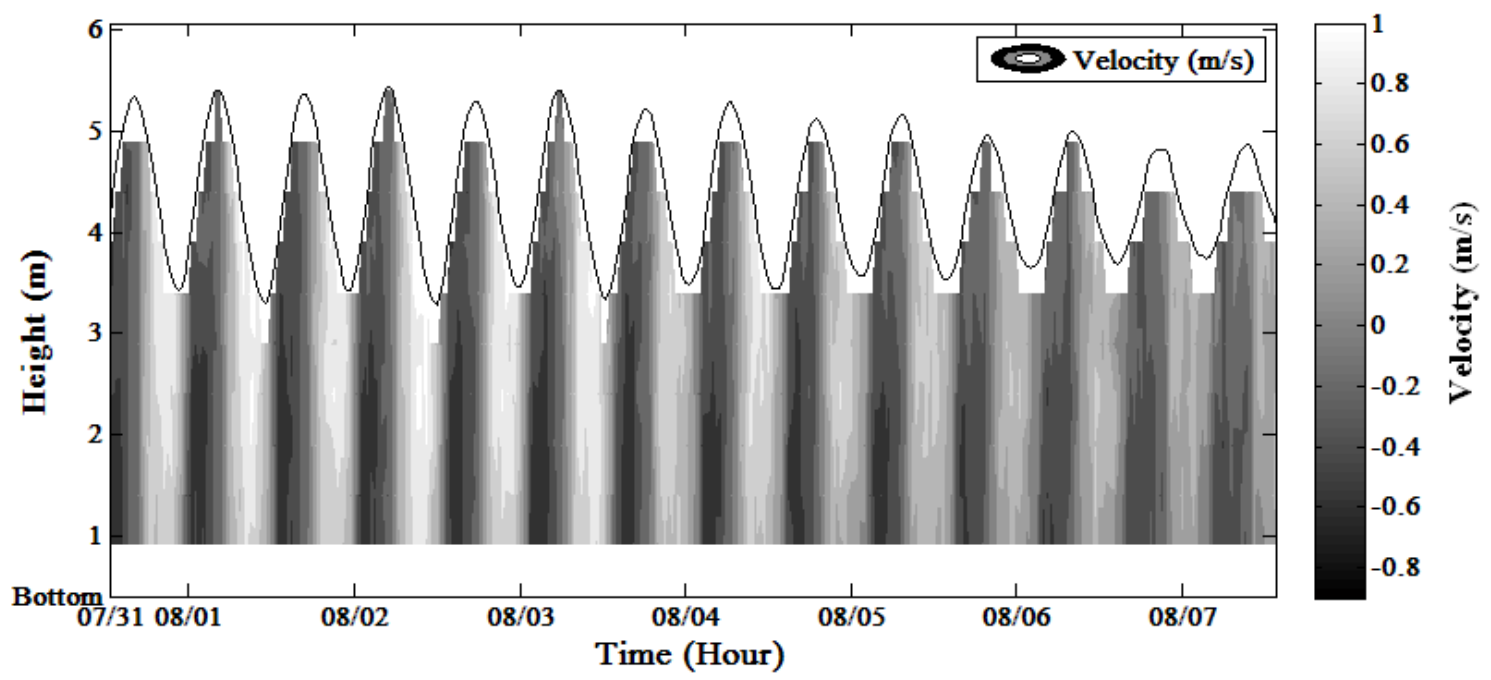

Figure 7. Data at 30 minute intervals of longitudinal velocity (m.s-1); Positive values: ebb; negative: flood; Black line: water column height.

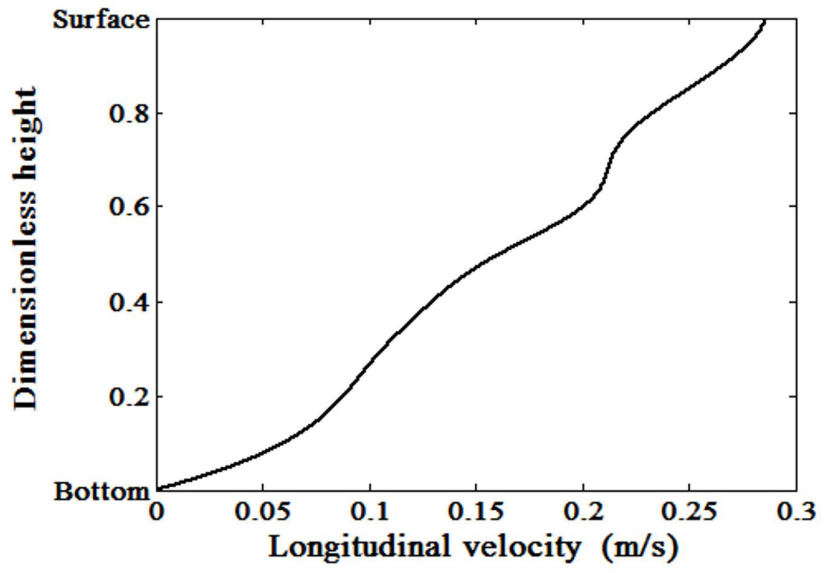

Figure 8. Average longitudinal velocity profile from 12:30 pm on July 31, 2015 to 1:30 pm on August 7, 2015.

\section{Layer Richardson number}

According to Figure 9, during most of the time $(77.9 \%$ of measurements), the value of $\mathrm{Ri}_{\mathrm{L}}$ was lower than 2 , indicating total mixture of the water column. This is reinforced by the difference between the surface and bottom salinity (Figure 6).

The layer Richardson number was greater than 20 during only $5.6 \%$ of the time. Only during these periods stratification was observed, when lower tidal shear during neap tides was less efficient in promoting mixture.

Under spring conditions (full moon on July 31 $1^{\text {st }}, 2015$ ), there was a lower Richardson number in comparison to neap tide conditions (waning moon on August $6^{\text {th }}, 2015$ ). This is expected, as the spring tides generated stronger currents and more tidal shear when compared to neap tides. Thereby, spring tides promoted more mixture of the water column. 
The degree of stratification depends on the amount of energy available to generate mixture in the water column. There is a link between degree of stratification and the turbulence generated by the tide (BARRETO; SCHETTINI, 2014). In this type of estuary, the tide has a large influence as a modulating effect. In general, the bottom salinity was shown to be virtually equal to the salinity at the surface under spring tide conditions, indicating small stratification during most of the time. Thus, the vertical flux of salt is quite small, and the mixture of salt occurs mainly in the longitudinal direction (MIRANDA et al., 2002).

It was observed that large variations in salinity between bottom and surface occurred in the final periods of the field campaign, under neap tide conditions. This is expected due to reduction in tidal shear as variations became smaller during neap tides. In general, when tide amplitudes are large (spring tides), there is more mixture in the water column, causing small layer Richardson numbers (Figure 9).

The $\mathrm{Ri}_{\mathrm{L}}$ assumes that the energy for mixing comes predominantly from the flow over the bed (CAVALCANTE et al., 2017). There was weak salinity stratification (well-mixed) during spring tides. The largest vertical stratification of salt (i.e. RiL > 20) was intensified during slack periods (i.e. lower velocities), because the turbulence generated by the flow near bottom was reduced and unable to generate mixture. In Buranhém estuary, bottom turbulence may not become effective $\left(\mathrm{Ri}_{\mathrm{L}}>20\right)$ especially during slack water and/or neap tides. The same behavior, with varying vertical structure as a function of tidal range has been observed by Siegle et al. (2009) for a similar sized estuary, under low discharge conditions.

\section{Estuary classification}

The overall classification of the estuary, according to the Hansen and Rattray Junior (1966) stratification and circulation parameter, is $1 \mathrm{~B}$. Temporal variations according to the tides resulted in varying stratification, moving from Type $1 \mathrm{~B}$ to $1 \mathrm{~A}$, as the tidal phase shifted from neap to spring conditions (Figure 10). The dashed lines in Figure 10 represent the relative proportion between the dispersive and advective processes. A proportion value ( $\mathrm{v}$ ) of one was estimated, meaning there is a dominance of turbulent diffusion over advection (MIRANDA et al., 2002). In other words, gravitational circulation was negligible and the salt transport in the upstream direction was due to turbulent diffusion (e.g. DIAS et al., 2016).

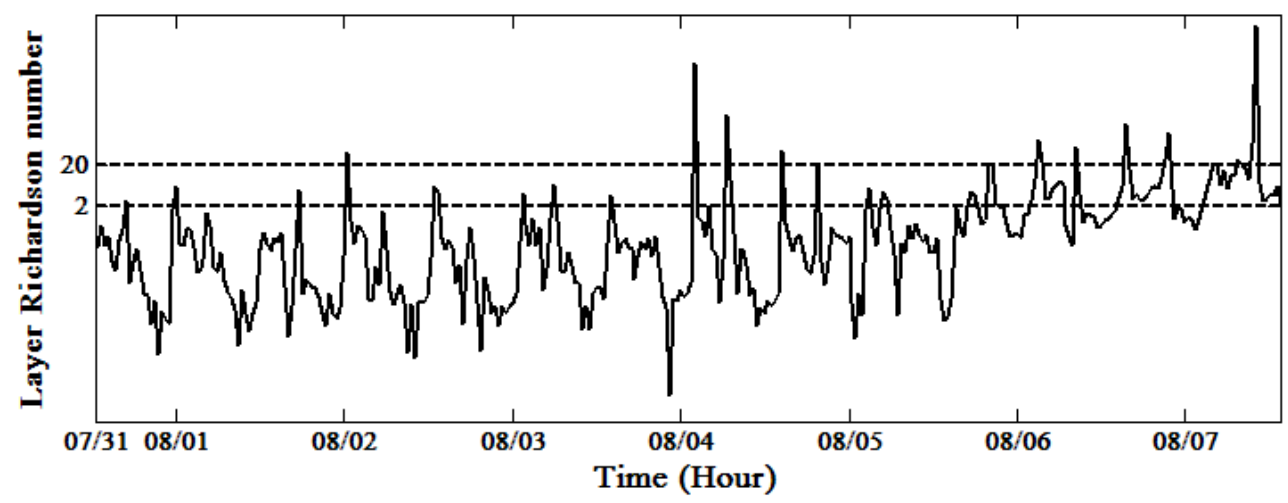

Figure 9. Layer Richardson number at 30 minute intervals from 12:30 pm on July 31, 2015 to 1:30 pm on August 7, 2015; Full moon (spring tide) on July 31, 2015 and waning moon (neap tide) on August 6, 2015.

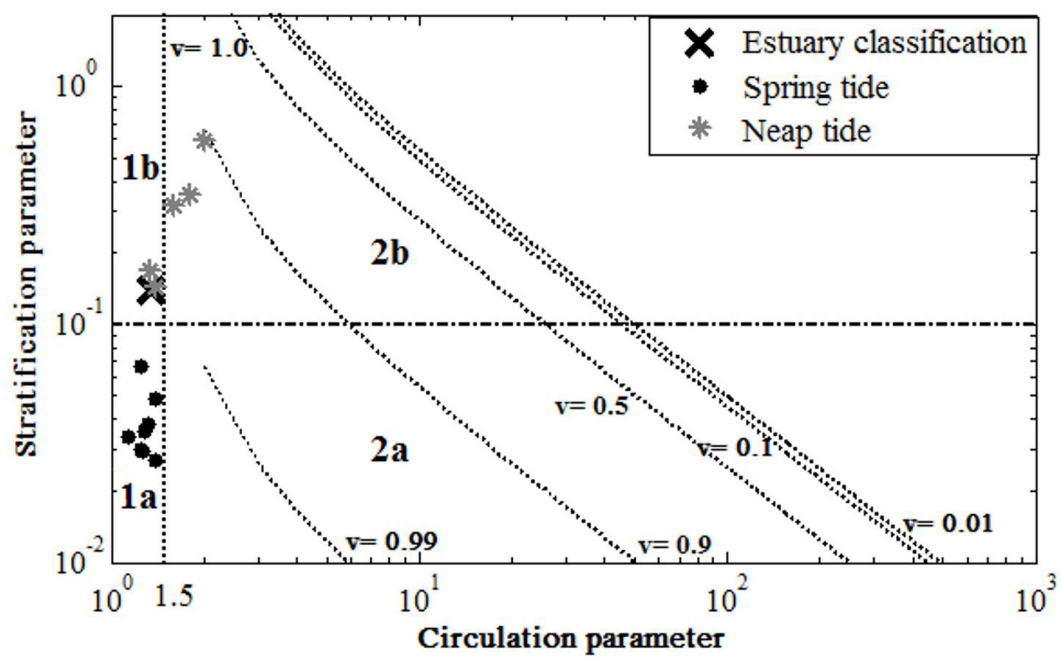

Figure 10. Hansen and Rattray Junior (1966) classification diagram of the Buranhém river estuary in Porto Seguro, Bahia; relative proportion $(0<\mathrm{v} \leq 1)$ between the dispersive and advective (dashed lines). 
The classification of the estuary was $2 \mathrm{~b}$ (partially mixed and highly stratified) during some neap tidal cycles. There was a high stratification during last three cycles. The baroclinic gradient pressure force is important. Similarly to the studies of Andutta et al. (2013) and Cavalcante et al. (2017), advection and diffusion contributed to the net up-estuary salt flux.

Stratification varies with tide condition, with spring tides being able to further mix the vertical structure. Vertical velocity gradients that generate vertical mixing overcome the stabilizing effects generated by vertical density gradients. This means that during large tidal ranges, gravitational circulation is inhibited. Based on the layer Richardson number (Figure 9), the estuary was classified as well-mixed. As for the Hansen and Rattray Junior (1966) classification, the estuary was of Type $1 \mathrm{~B}$, with some alternation between $1 \mathrm{~A}$ (during spring tides) and $1 \mathrm{~B}$ (during neap tides). Estuaries of Type 1 have residual flow downstream the entire water column, while the estuary's transport of salt in the landward direction occurs by the process of turbulent diffusion. Also, Type 1 estuaries are driven by tides, which have sufficient energy to induce vertical stratification and vertical homogenization in the water column.

In general, a well-mixed estuary is characterized by a larger tide influence, with river flow being of secondary importance. Our dataset spanned dry conditions under ENSO (El Niño/Southern Oscillation) conditions. Increased river discharge would result in increased stratification in the water column, when compared to observed data. Such conditions will be important for local ecosystem development, because there is reduced vertical flux of matter and energy, such as nutrients and heat, under more stratified conditions (CAVALCANTE et al., 2013). Although the present study does not cover the wet period, the Buranhém estuary may become partially stratified or stratified during neap tides (Figure 10), after large rainfall events or other periods with larger river flows (Figure 3). Therefore, the classification could be different in other phases of the year. Although our results focused only on dry conditions, they provide important background information for the region. A thorough understanding of the study area requires the replication of these field measurements under larger river discharges.

\section{CONCLUSION}

Based on in situ data, a first assessment of the hydrodynamics of the Buranhém river estuary is presented. Results show the influence of varying tides on the system, under low river discharge conditions.

Semidiurnal tides from micro to mesotidal range were observed. During spring tide conditions, the importance of the tidal influence was amplified as expected, which reflected on weak vertical stratification.

Most of the time, the value of the $\mathrm{Ri}_{\mathrm{L}}$ indicated a total mixture in the water column. The largest values were found close to slack water and/or neap tides.

Hansen and Rattray Junior (1966) classification diagram indicated the estuary was of Type $1 \mathrm{~B}$ - well-mixed with a dominant turbulent diffusion process, which is typical of tide-driven estuaries.

Although these results represented dry conditions, they form important background information on the local dynamics. We recommend for future studies in the region to assess the influence of the varying river discharge ranges and their effects on the estuarine dynamics.

\section{ACKNOWLEDGEMENTS}

The authors are thankful to the anonymous reviewers for their valuable comments.

This article is part of the project Environmental diagnosis and monitoring of the estuary of the Buranhém river, Porto Seguro, Bahia, sponsored by National Council of Technological and Scientific Development (CNPq), process n ${ }^{\circ} 447545 / 2014-0$, a collaboration between the Federal University of Southern Bahia (UFSB), Federal University of Itajubá (UNIFEI), Oceanographic Institute of the University of São Paulo (IOUSP) and State University of Santa Cruz (UESC). A.T.A. and E.S. are sponsored by $\mathrm{CNPq}$ research fellowships.

We are also grateful to the Coordination for the Improvement of Higher Education Personnel (CAPES), to the Brazilian Navy and to the Department of Environment of Porto Seguro.

\section{REFERENCES}

ANA - AGÊNCIA NACIONAL DE ÁGUAS. Hidroweb: séries históricas. 2016. Available from: < http://hidroweb.ana.gov.br/>. Access on: 05 jan. 2016.

ANDUTTA, F. P.; MIRANDA, L. B.; SCHETTINI, C. A. F.; SIEGLE, E.; SILVA, M. P.; IZUMI, V. M.; CHAGAS, F. M. Temporal variations of temperature, salinity and circulation in the Peruípe river estuary (nova Viçosa, BA). Continental Shelf Research, v. 70, p. 36-45, 2013. http://dx.doi.org/10.1016/j.csr.2013.03.013.

ASP, N. E.; SCHETTINI, C. A. F.; SIEGLE, E.; SILVA, M. S.; BRITO, R. N. R. The dynamics of a frictionally-dominated Amazonian estuary. Brazilian Journal of Oceanography, v. 60, n. 3, p. 391-403, 2012. http:// dx.doi.org/10.1590/S1679-87592012000300011.

BARretTO, G. A. M.; SCHETTINI, C. A. F. Papel da Maré e da descarga fluvial na circulação do Estuário do Rio Araranguá. Revista Brasileira de Recursos Hídricos, v. 19, n. 3, p. 7-17, 2014. http://dx.doi. org/10.21168/rbrh.v19n3.p7-17.

BÉRGAMO, A. L. Caracterização da hidrografia, circulação e transporte de sal: Barra de Cananéia, Sul do Mar de Cananéia e Baía de Trapandé. 2000. 254 f. Dissertação (Mestrado em Ciências) - Instituto de Oceanografia, Universidade de São Paulo, São Paulo, 2000.

BÉRGAMO, A. L.; MIRANDA; L. B.; CORRÊA, M. A. Estuários: programas para o processamento e análise de dados hidrográficos e correntográficos. São Paulo: Universidade de São Paulo, 2002. 16 p. Relatórios Técnicos.

CAMERON, W. M.; PRITCHARD; D. W. Estuaries. In: HILL, M. $\mathrm{N}$. (Ed.). The sea: ideas and observations on progress in the study of the seas. New York: Interscience, 1963. p. 306-324.

CAVALCANTE, G. H.; FEARY, D. A.; KJERFVE, B. Effects of tidal range variability and local morphology on hydrodynamic behavior and salinity structure in the Caeté River Estuary, North Brazil. International Journal of Oceanography, v. 2013, p. 1-10, 2013. http://dx.doi.org/10.1155/2013/315328. 
CAVALCANTE, G.; MIRANDA, L. B.; MEDEIROS, P. R. P. Circulation and salt balance in the São Francisco river Estuary (NE / Brazil). Brazilian Journal of Water Resources, v. 22, p. e31, 2017. http:/ / dx.doi.org/10.1590/2318-0331.021720170003.

DIAS, F. J. S.; CASTRO, B. M.; LACERDA, L. D.; MIRANDA, L. B.; MARINS, R. V. Physical characteristics and discharges of suspended particulate matter at the continent-ocean interface in an estuary located in a semiarid region in northeastern Brazil. Estuarine, Coastal and Shelf Science, v. 180, p. 258-274, 2016. http://dx.doi.org/10.1016/j. ecss.2016.08.006.

DYER, K. R. Estuaries: a physical introduction. 2nd ed. England: John Wiley \& Sons, 1997. 195 p.

GOMES, V. J. C.; FREITAS, P. T. A.; ASP, N. E. Dynamics and seasonality of the middle sector of a macrotidal estuary. Journal of Coastal Research, v. 2, n. 65, p. 1140-1145, 2013. http://dx.doi. org/10.2112/SI65-193.1.

GONZÁLEZ, C. J.; ÁLVAREZ, Ó.; REYES, J.; ACEVEDO, A. Two-dimensional modeling of hydrodynamics and sediment transport in the San Pedro tidal creek (Cadiz Bay): morphodynamical implications. Ciencias Marinas, v. 36, n. 4, p. 393-412, 2010. http:// dx.doi.org/10.7773/cm.v36i4.1624.

HANSEN, D. V.; RATTRAY JUNIOR, M. New dimensions in estuary classification. Limnology and Oceanography, v. 11, n. 3, p. 319-326, 1966. http://dx.doi.org/10.4319/lo.1966.11.3.0319.

IBGE - INSTITUTO BRASILEIRO DE GEOGRAFIA E ESTATÍSTICA. IBGE Cidades. 2017. Available from: <https:// cidades.ibge.gov.br/brasil/ba/porto-seguro/panorama>. Access on: 24 out. 2017.

IBGE - INSTITUTO BRASILEIRO DE GEOGRAFIA E ESTATÍSTICA. IBGE lança mapa de densidade demográfica de 2010.2013. Available from: $<$ http:// saladeimprensa.ibge.gov.br/noticias?view= noticia\&id $=1 \&$ busca $=1 \&$ idnoticia $=2501>$. Access on: 16 maio 2015 .

LIU, W. C.; CHAN, W. T.; YOUNG, C. C. Modeling fecal coliform contamination in a tidal Danshuei River estuarine system. The Science of the Total Environment, v. 502, p. 632-640, 2015. PMid:25302451. http://dx.doi.org/10.1016/j.scitotenv.2014.09.065.

MAZDA, Y.; KANAZAWA, N.; WOLANSKI, E. Tidal asymmetry in mangrove creeks. Hydrobiologia, v. 295, n. 1-3, p. 51-58, 1995. http:// dx.doi.org/10.1007/BF00029110.

MIRANDA, L. B.; CASTRO, B. M.; KJERFVE, B. Princípios de oceanografia física de estuários. São Paulo: Editora da Universidade de São Paulo, 2002.

PAIVA, B. P.; SCHETTTINI, C. A. F.; PEREIRA, M. D.; SIEGLE, E.; MIRANDA, L. B.; ANDUTTA, F. P. Circulation and suspended sediment dynamics in a tropical estuary under different morphological setting. Anais da Academia Brasileira de Ciencias, v. 88, n. 3, p. 1265-1276, 2016. PMid:27598844. http://dx.doi.org/10.1590/0001-3765201620150620.
PEREIRA, M. D.; SIEGLE, E.; MIRANDA, L. B.; SCHET'TINI, C. A. F. Hidrodinâmica e transporte de material particulado em suspensão sazonal em um estuário dominado por mare: Estuário de Caravelas (BA). Revista Brasileira de Geofísica, v. 28, n. 3, p. 427-444, 2010. http:// dx.doi.org/10.1590/S0102-261X2010000300008.

RIGO, D. Análise do escoamento em regiões estuarinas com manguezais - medições e modelagem na Baía De Vitória, ES. 2004. 140 p. Tese (Doutorado em Engenharia Oceânica) - Instituto Alberto Luiz Coimbra de PósGraduação e Pesquisa de Engenharia, Universidade Federal do Rio de Janeiro, Rio de Janeiro, 2004.

SCHETTINI, C. A. F.; MIRANDA, L. B. Circulation and suspended particulate matter transport in a tidally dominated estuary: Caravelas Estuary, Bahia, Brazil. Brazilian Journal of Oceanography, v. 58, n. 1, p. 1-11, 2010. http://dx.doi.org/10.1590/S1679-87592010000100001.

SCOT'T, S. F. Canonical parameters for estuary classification. Estuarine, Coastal and Shelf Science, v. 36, n. 6, p. 529-540, 1993. http://dx.doi. org/10.1006/ecss.1993.1032.

SIEGLE, E.; SCHETTINI, C. A. F.; KLEIN, A. H. F.; TOLDO JUNIOR, E. E. Hydrodynamics and suspended sediment transport in the Camboriú estuary - Brazil: Pre jetty conditions. Brazilian Journal of Oceanography, v. 57, n. 2, p. 123-135, 2009. http://dx.doi.org/10.1590/ S1679-87592009000200005.

TOWNEND, I.; FLETCHER, C.; KNAPPEN, M.; ROSSINGTON, K. A. Review of salt marsh dynamics. Water and Environment Journal, v. 25 , n. 4, p. 477-488, 2011. http://dx.doi.org/10.1111/j.17476593.2010.00243.x.

WOLANSKI, E. Hydrodynamics of mangrove swamps and their coastal waters. Hydrobiologia, v. 247, n. 1-3, p. 141-161, 1992. http:// dx.doi.org/10.1007/BF00008214.

\section{Authors contribuitions}

Ana Carolina Rodrigues de Sá Silva: participated in the field, analysis, interpretation and discussion of results, writing and revision of the article.

Marcos Eduardo Cordeiro Bernardes: participated in the field, responsible for reviewing the data analysis, discussion of the results, writing and revision of the article.

Arcilan Trevenzoli Assireu: responsible for reviewing the data analysis, writing and revision of the article.

Eduardo Siegle: responsible for reviewing the data analysis, discussion of the results, writing and revision of the article.

Paulo Henrique Gomes de Oliveira Sousa: participated in the field, responsible for reviewing the data analysis, writing and revision of the article.

Dustin Brown: responsible for reviewing the data analysis, writing and revision of the article. 